\title{
Promotional Strategies and Sales Performance of Insurance Companies
}

\author{
Kinoti, P. N. \\ Department of Business Administration \\ Chuka University, Kenya. \\ Dr. Nkari, I. M. \\ Kathuni, L. K. \\ Lecturer \\ Department of Business Administration \\ Chuka University, Kenya.
}

\begin{abstract}
Promotional strategies play a key role in sales performance of any institution. Insurance products are generally difficult to sell and require well thought out marketing strategies that will include persuasive promotional activities. A survey by Insurance Regulatory Authority (2013) found low consumer demand for insurance products as the biggest challenge to the growth of the industry in Kenya. Engaging in promotional activities is costly and the results uncertain. Hence the purpose of this study was to determine the effect of promotional activities on sales performance of Insurance companies. The study was guided by the following specific objectives: to determine the effect of sales promotion, advertising, personal selling and public relations on sales growth of insurance companies. The study adopted a descriptive research design. The population of the study comprised of the branch managers, unit managers and salespeople of insurance companies operating in Embu County, Kenya. The sample size of the study was 175 respondents. A response rate of $85.7 \%$ was achieved. Data was analyzed using both descriptive and inferential statistics. Overall, the study established that promotional activities significantly affected sales performance of insurance companies even though at an individual level, public relations did not have any significant effect on sales performance. The study recommends that insurance companies should engage in maximum utilization of the entire promotion mix to enhance sales growth. The study suggests that further research be carried out to determine the effect of the entire marketing mix on sales performance of the insurance and other related industries using different performance measurements. Future researchers will utilize this study as a reference point. Policy makers can reference the study in formulating fiscal policies for the insurance and overall financial sector.
\end{abstract}

Keywords: Insurance Companies, Promotion Strategies, Promotion Mix

\subsection{Introduction}

Promotion is the direct way an organization attempts to reach its publics and is performed through the five elements of promotion mix namely advertising, sales promotion, personal selling, public relations, and direct marketing (Czinkota $\&$ Ronkainen, 2004). Promotion is one of the elements of marketing mix among other elements like Product, Price, and Place, which constitute the 4ps of marketing (Mc Carthy, 1996). Marketing mix decision must be made with the objective of influencing the trade channels as well as the final consumer and in return sales.

Promotion brings an interactive dialogue between an organization and its customers and it takes place during the preselling, selling, consuming and post- consuming stages. Marketers use the marketing mix that are defined as the set of tools that a firm uses to pursue its marketing objectives in the target market (Kotler \& Armstrong, 2000). The importance of promotion $\mathrm{s}$ has been increasing rapidly due to the ever increasing competitive market conditions. Companies need to find the best way to access the customers and make sure that they are satisfied with their own products and services. The companies' way of communicating and promoting their product affects the companies' market performance and it leads to financial success or failure (Chen, 2009). Consequently, good marketing practices by insurance companies in Kenya are imperative if the industry is to effectively play a key role in the overall development of the country.

According to Richard, Timothy, George and Gerry (2009) sales performance encompasses three specific areas; product market performance where sales and market share are involved; firm performance encompassing return on assets and investment and lastly, shareholders' return where shareholder return and economic value added are involved. Performance in a company is typically expressed in terms of sales, market share or profitability. Marketing decision variables according to Gatingnon (1993) are basically of two types. 
The first group deals with estimating the impact of marketing decision variables while the second group deals with guidelines as to what level the marketing variations should be. This study measures sales performance as indicated by volume of sales which correlates directly with profitability and market share.

Gatington, 1993 asserts that marketing efforts do not impact performance (product sales or market share) independently of each other. Promotional mix activities need to be coordinated because they interact to determine performance in terms of growth. This will help managers to take advantage of the complementary value of the mix activities and to avoid incompatibility between the mix activities given budgetary constraints and nature of the variables themselves. Evidence from reviewed literature shows that advertising effectiveness is enhanced by the quality of the product, prior sales persons' contacts, retail outlets availability and higher or lower price depending on the advertising medium (Parasad \& Ring, 1976).

Okyere, Agypong and Nyarku (2011) affirmed that marketing firms use various tools of communication to promote their offerings in order to achieve their promotional objectives under the marketing mix. Etzel, Walker and Stanton (2001) noted advertising, personal selling, sales promotion and public relations while Kotler and Armstrong (2008) added direct marketing. Sponsorship has been propounded as the sixth mode or channel of marketing communication mix (Jobber, 2004; Fill, 2005; Kotler \& Keller, 2009).

A study by Irene (2015) established that insurance companies widely used advertising, direct marketing, public relations, personal selling and sales promotion in their communication practices. The study established that marketing communication practices influence performance insurance companies with the major influence being caused by advertising. Aliata, Odondo, Ailo, Ojero, Abong and Odera (2012) found that sales promotion was the highest ranked promotional mix element with regards to its effect on sales volume of banks in Kenya. Personal selling was ranked second, advertising third, and public relations fourth while direct marketing was ranked lowest. The study found that there was a positive relationship between promotional strategies expenditure and bank performance.

A survey conducted by Kyeva (2005) on the marketing mix used by life insurance companies in Kenya in responding to the challenge of Hiv/Aids pandemic established that most of the insurance companies (78\%) utilized the 7ps of service marketing although the order in which they were utilized varied from company to company. The first priority was given to product benefits, price, place, promotion, people, process and physical evidence in that order. Customer needs was the major factor that influenced the choice of the mix in particular markets. Abiodun (2014) found that advertising, personal selling and public relations took highest priority among marketers of insurance services in Nigeria.

In an environment characterized by low consumer demand for a particular product, promotional activities play a key role in the performance of a firm operating in that environment. In the emerging dynamism of the business environment, it is concluded that no progressive organization can afford to overlook marketing (Abubakar, 2014). This applies even to the insurance companies whose environment dynamism in the current times is posing many challenges including intense competition, globalization and technological advancement and therefore calling for promotional activities. It has, therefore become essential to use all the resources and practices that marketing offers to survive and succeed in the ever changing business environment. Kenya Vision 2030 projects insurance to grow by at least $10 \%$ of the country's GDP against the current penetration of $2.93 \%$. Comparing other countries in Africa such as South Africa whose insurance premium to GDP ratio was $15 \%$ in 2013, Kenya has a low rate of penetration (Insurance Regulatory Authority, 2014). Despite the great number of promotional activities available and their unique advantages to serve a specific target market, their effect on insurance sales growth in Kenya is not well known. A study by Kivuva (2003) on the effect of promotional elements on sales volumes in service industry found that those services which were on promotion tended to have more demand than those which were not. However, the study only focused on banking industry and used sales volumes as the measure of sales performance. This study used more measures of sales performance. Ondiri (1998) did his study on the effect of choice of promotion elements in profit organizations and found that the choice of promotional elements in profit organizations did not have any effect on sales performance. Due to the identified gaps, there was need to carry out another study to offer more insights on the effect of promotional activities on sales performance of insurance companies. There was therefore need for this study which sought to examine the effect of promotional activities on sales performance of insurance companies in Embu County, Kenya.

\subsection{Methods}

To establish the association among promotional strategies and sales performance descriptive research design was adopted. This design facilitated in ascertaining the characteristics of the variable of interest in subject of interest (Kothari, 2008).

The descriptive research design was suitable for this study since as pointed out by (Mugenda \& Mugenda, 2003) it aided in explaining the influence of promotional activities on sales performance of insurance companies. Population of 
the study comprised of the branch managers, unit managers and salespeople of insurance companies operating in Embu Town, whose number stood at 182. Random sampling was used to obtain representatives of sales people while census method was used for branch and unit managers. To determine the sample size for the sales people, a formula suggested by Krejcie and Morgan (1970) was used as follows:

$$
s=X^{2} N P(1-P) / d^{2}(N-1)+X^{2} P(1-P) \text {. }
$$

Where:

$\mathrm{s}=$ required sample size, $\mathrm{x}^{2}=$ the table value of chi-square for 1 degree of freedom at the desired confidence level (3.841), $\mathrm{N}=$ population size, $\mathrm{P}=$ the population proportion (assumed to be .50 since this would provide the maximum sample size) and $\mathrm{d}=$ the degree of accuracy expressed as a proportion (.50). The sample size (s) was determined as 153 respondents. The individual sales persons were selected using a table of random numbers. Data was collected using a closed ended questionnaire which was administered by the researcher through a drop and pick method. This method was appropriate since it increased response rate.

The study variables were operationalized and measured using direct measures and five point Likert-type rating scales ranging from $1=$ No extent to $5=$ To a very large extent. Data was analyzed using both descriptive statistics (percentages, mean and standard deviation) and inferential statistics (chi square and correlation analysis).

\subsection{Results and Discussions}

A total of 175 questionnaires were administered to all respondents. A total of 150 questionnaires were filled and returned. This represented a response rate of $85.71 \%$.

\subsection{Reliability and Validity}

The study sought to establish the reliability of the research instrument by computing the Cronbach's Alpha coefficient in regard to the elements in the study variables. According to Kothari (2004) a coefficient of 0.7 and above is deemed reliable. The results are summarized in Table 1 below.

Table 1: Reliability Results

\begin{tabular}{lcc}
\hline Variable & Item & Cronbach's Alpha \\
\hline Sales Promotion & 9 & 0.898 \\
Advertising & 10 & 0.882 \\
Personal selling & 8 & 0.743 \\
Public Relations & 8 & 0.891 \\
Sales growth & 14 & 0.781 \\
\hline
\end{tabular}

The Cronbachs alpha reliability statistics in Table 1 above shows that all the variables had reliability statistics greater than 0.7 indicating that the variables were reliable for the study. Sales promotion had the highest reliability $(0.898)$ and personal selling had the lowest at 0.743 .

\subsection{Descriptive Statistics}

Promotional activities constituted the independent variables of the study. The constucts investigated to evaluate their effect on sales performance included sales promotion, personal selling, advertising and public relations.

Table 2: Summary of Descriptive Statistics for Promotional Activities

\begin{tabular}{llll}
\hline Variable & $\mathrm{N}$ & Mean & SD \\
\hline Sales Promotion & 150 & 2.68 & 1.217 \\
Advertising & 150 & 3.13 & 1.082 \\
Personal Selling & 150 & 3.94 & 0.942 \\
Public Relations & 150 & 2.60 & 1.161 \\
\hline
\end{tabular}

The results in the Table 2 above reveal that personal selling had the highest mean score (mean score $=3.94, \mathrm{SD}=0.942$ ) implying that personal selling is an effective promotional activities in the sale of insurance products followed by advertising (mean score $=3.13, \mathrm{SD}=1.082$ ). Sales promotion and public relations recorded the lowest (mean scores of $2.68, \mathrm{SD}=1.217$ and $2.60, \mathrm{SD}=1.161)$ respectively. 


\subsection{Sales Performance of Insurance Companies}

The constructs used to describe sales performance of Insurance companies were sales volume and Market Share. The Table below contains a summary of the individual indicators of the achieved sales performance.

\section{Summary of Descriptive Statistics for Sales performance}

Table 3: Respondents Score on Descriptive Statistics for Sales Growth

\begin{tabular}{llll}
\hline Variable & $\mathrm{N}$ & Mean & SD \\
\hline Sales volume & 150 & 4.13 & .894 \\
Market share & 150 & 4.42 & .743 \\
Sales growth & 150 & 4.27 & .819 \\
\hline
\end{tabular}

From the Table 3 above, it can be observed that the mean score for the market share used to measure sales growth was 4.42. It means that to a large extent promotional activities affected market share of insurance companies and thus sales performance. Similarly, sales volumes were affected by promotional activities to a large extent.

\subsection{Correlation Analysis}

Correlation analysis using Pearson product moment correlation coefficient technique was used to establish the relationship between promotional activities and sales growth of insurance companies.

The results of the correlation analysis indicated that the relationship between sales promotion and sales growth is moderate, positive and statistically significant $(\mathrm{r}=0.522, \mathrm{p}$-value $=0.000)$. The relationship between advertising and sales growth was weak, positive and statistically significant $(\mathrm{r}=0.202$, $\mathrm{p}$-value $=0.013)$. The relationship between personal selling and sales growth was weak, positive and statistically significant $(r=0.332$, p-value $=0.000)$. Results in Table 4 indicates that the correlation between sales promotion, advertising, personal selling and sales growth was $0.522,0.202,0.332$ respectively. All these correlations were positive indicating that increase in the level of promotional activities lead to an increase in sales growth. However, the relationship between public relations and sales growth was weak, negative and not statistically significant $(r=-0.132, p$-value $=0.108)$. This justifies the reason as to why in a dynamic business environment, companies need to increase utilization of promotional activities in order to realize sales growth.

\subsection{Summary of the Research Findings}

The main objective of the study was to determine the effect of promotional activities on sales performance of insurance companies in Embu County, Kenya. This was achieved by analyzing the effect of sales promotions, advertising, personal selling and public relations on sales growth of insurance companies in Embu County.

The first hypothesis sought to determine the relationship between sales promotions and sales growth of insurance companies in Embu County. The results established that sales promotion, significantly affected sales growth with Pearson's Chi-Square at 23.443 and p- values of 0.003. The results further indicated that there existed a moderate, positive and statistically significant relationship between sales promotions and sales growth at $5 \%$ significance level with correlation value of 0.522 . Therefore, the null hypothesis that sales promotion had no significant effect on sales growth of insurance companies was rejected. The results implied that an increase or improvement in the utilization of sales promotions led to increase in sales growth of insurance companies.

The second hypothesis sought to determine the relationship between advertising and sales growth of insurance companies in Embu County. The study established that advertising significantly affected sales growth with Pearson's Chi-Square at 19.768 and p- value of 0.0135 . The results further indicated that there existed a moderate, positive and statistically significant relationship between advertising and sales growth at 5\% significance level with correlation value of 0.202. Therefore, the null hypothesis that advertising had no significant effect on sales growth of insurance companies was rejected. The results implied that an increase or improvement in the utilization of advertising led to increase in sales growth of insurance companies.

The third hypothesis sought to determine the relationship between personal selling and sales growth of insurance companies in Embu County. The study established that personal selling significantly affected sales growth with Pearson's Chi-Square at 34.238 and p- value of 0.000 . The results further indicated that there existed a weak, positive and statistically significant relationship between advertising and sales growth at 5\% significance level with correlation value of 0.332 . Therefore, the null hypothesis that personal selling had no significant effect on sales growth of insurance companies was rejected. The results implied that an increase or improvement in the utilization of personal selling led to increase in sales growth of insurance companies. 
The fourth hypothesis sought to establish the relationship between public relations and sales growth of insurance companies in Embu County. The study established that public relations did not significantly affected sales growth with Pearson's Chi-Square at 9.278 and p- value of 0.319. The results further indicated that there existed a weak, negative and statistically insignificant relationship between public relations and sales growth at 5\% significance level with correlation value of -0.132 . Therefore the null hypothesis that public relations had no significant effect on sales growth was accepted. The results implied that public relations activities had no statistically significant influence on sales growth of insurance companies in Embu County.

\subsection{Recommendations}

Based on the findings of the study, the following recommendations are made to management of insurance companies and government regulators: Insurance companies should emphasize on the use of free consultations to their clients to increase sales as part of sales promotion towards enhancement of sales growth. They also need to stress on personal selling activities since they were found to affect sales growth most significantly. Advertising activities (print, electronic, outdoor and social media) should be exploited as a means of improving performance. There is need for insurance companies to carefully evaluate the public relations activities they engage in since the tool was found not to be very effective in contributing towards sales growth.

\subsection{Suggestions for Further Studies}

Based on the findings of this study, a study using other marketing mix elements beyond sales promotions will determine other effect on sales growth of insurance industry and other related industries. A study using other measures of performance other than sales performance can be carried out to determine their effect on sales growth of insurance industry and other related industries. A study to establish why public relations activities among other promotional activities had statistically insignificant contribution to sales growth would be appropriate.

\section{References}

Abubakar, H.S. (2014). Impact of Marketing Communication on Financial Performance of Banks: A study of First bank of Nigeria plc. Proceedings of 25th International Business Research Conference, Taj Hotel, Cape Town, South Africa, 13 - 14 January.

Aliata, V.L., Odondo, J., Ailo, F.O., Ojero, P.B., Abong, O. B. E. \& Odera, O. (2012). Influence of Promotional Strategies on Banks Performance. International Journal of Business, Humanities and Technology, 2(5): 17-26.

Association of Kenya Insurers (2014). Insurance Industry Annual Report 2013. Nairobi: AKI.

Association of Kenya Insurers. (2009). Insurance Industry Annual Report. Retrieved 2 February 2011, from http://www.akinsure.or.ke/public_site/webroot/cache/article

Chen, H. \& Green, R.D. (2009). Marketing Mix and Branding: Competitive Hypermarket Strategies

Chen, N. (2009). Institutionalizing Public Relations: A Case Study of Chinese Government

Czinkota, M.R. \& Ronkainen, L.A. (2004), International Marketing, $7^{\text {th }}$ Edition, Ohio: Harcourt.Inc.

Donelly, (Jr.), J.H. \& Peter, J.P. (1998). Marketing Management: Knowledge and: McGraw-Hill Companies Inc.

Etzel, M.J., Walker, B.J. \& Stanton, W.J. (2001). Marketing (12th ed.). New York: McGraw-Hill Companies Inc.

Fill, C. (2005). Marketing Communication: Engagement, Strategies and Practices (4th ed.). England: Pearson Education Limited.

Gatington, H. (1993). Marketing Mix Model (eds) Handbook in OR and MS Vo. 5 Elsievier science Publisher..

Harris, T. (2002). Value-Added Public Relations: The Secret Weapon in Integrated Marketing. Chicago: NTE Books.

Insurance Regulatory Authority (2013). Who Are the Players in The Insurance Market in Kenya (pp. 1)? Nairobi Insurance Regulatory Authority.

Insurance Regulatory Authority, (2014). Statistical Bulletin. Nairobi: IRA.

Irene, M.M. (2005). Influence of Marketing Communications on Performance of Insurance Companies in Kenya. (Unpublished Masters Project, University of Nairobi, Kenya).

Jobber, D. (2004). Principles and Practice of Marketing (4th ed.). Berkshire: McGraw-Hill International Limited.

Kivuva, P.T. (2003). A Case Study on Effect of Promotional Element on Sales in Service Industries. (Unpublished Masters Project, Kenyatta University, Kenya).

Krejcie, R. V. \& Morgan, D.W. (1970). Determining Sample Size for Research Activities. Educational and Psychological Measurement: University of Minnesota, Duluth.

Kothari, C. R. (2008). Research methodology; Methods and techniques. New Delhi: Age Publishers

Kothari, C. R. (2004). Research methodology; Methods and techniques. New Delhi: Age Publishers

Kotler, P. \& Armstrong, G. (2008). Principles of Marketing (12th ed.). London: Pearson Education Limited.

Kotler, P. \& Armstrong, G. (2000). Principles of Marketing (12th ed.). London: Pearson Education Limited. 
Kotler, P. \& Keller, K.L. (2009). Marketing management (13th ed.). New Jersey: Pearson Education Inc.

Kyeva, M.B. (2005). A Survey of Marketing Mix Used by Life Insurance Companies in Responding to Challenges of HIV/AIDS: (Unpublished Masters Project, University of Nairobi, Kenya),

Lancaster, G. \& Massingham, L. (1999). Essentials of Marketing. London: McGHill Masters Project of UON

McCarthy, J. (1996). Basic Marketing: Journal of Marketing Education.New York: D. Irwin.

Mugenda, O. M. \& Mugenda, A. G. (2003). Research Methods: Quantitative \& Qualitative

Okyere, N.Y., Agypong, G.K., \& Nyarku, K.M. (2011). The Effect of Marketing Communications on the Sales Performance of Ghana Telecom (Vodafone, Ghana). International Journal of Marketing Studies, 3(4), 50-62.

Ondiri M. (1988). "A Case Study on the Factors Influencing Choice of Promotional Elements in Organization." (Unpublished Masters Project, University of Nairobi).

Richard, P. J., Timothy, M. D., George, Y., \& Gerry, J., (2009). Measuring Organizational Performance: Towards Methodological Best Practice. The Academy of Management Journal. 